\title{
First Intervention in Firearm Injuries and Management of Compliations
}

\section{Ateşli Silah Yaralanmalarında İlk Müdahale ve Komplikasyonların Yönetimi}

\author{
๑Abbas Tokyay, @Sezai Özkan, @Necip Güven, @Ulan İsmailov, Aytekin Dikici
}

Van Yüzüncü Yıl University, Faculty of Medicine, Department of Orthopedics and Traumatology, Van, Turkey

\begin{abstract}
Aim: Soft tissue, neurovascular injuries and bone fractures are seen in the extremity as a result of firearm injuries. The fact that these injuries are violent and that forensic incidents are more frequent, especially in young people, make treatment more difficult. Our aim in this study is to evaluate the effects of a stepwise approach to neurovascular, soft tissue injuries and bone fractures on the final treatment results in firearm-related musculoskeletal injuries.

Material and Method: This study retrospectively evaluated patients over the age of 18 who had firearm-related extremity injuries and received surgical treatment between 2015 and 2020.Demographic characteristics of the patients, injury sites, accompanying neurovascular injuries, patients who received first aid, final treatment results, developing complications and management of the complications were evaluated.

Results: The mean age of 54 patients ( 52 males, 2 females) in the study was 28.3 (age range 19-61) years. Twenty-nine (53.7\%) lower extremity, 20 (37.1\%) upper extremity, and 5 (9.2\%) both lower and upper extremity injuries were detected. Vascular injury was detected in $3(5.5 \%)$ patients, amputation in $3(5.5 \%)$ and nerve injury in $6(11.1 \%)$ patients. Five $(9.2 \%)$ of 6 patients, underwent fasciotomy in the early period because the development of compartment syndrome was highly anticipated. In one of the patients, fasciotomy was performed due to the development of the compartment syndrome during the follow-up. The most common complication we encountered was loss of joint range of motion in 7 (12.9\%) patients.

Conclusion: Switching to definitive treatment after antibiotherapy, bone fixation and serial debridements in the early period with a multidisciplinary and damage-controlled approach to firearm injuries positively affects the success of treatment. In addition, necessary consents should be obtained to minimize medico-legal problems.
\end{abstract}

Keywords: Firearm injuries, neurovascular injury, fasciotomy, complications
Öz

Amaç: Ateşli silah yaralanmaları sonucu ekstremitede yumuşak doku, nörovasküler yaralanmalar ve kemik kırıkları görülmektedir. Bu yaralanmaların şiddete yönelik olması ve adli olayların gençlerde daha sık görülmesi tedaviyi daha da zorlaştırmaktadır. Bu çalışmadaki amacımız, ateşli silahlarla ilişkili ekstremite yaralanmalarında nörovasküler, yumuşak doku yaralanmaları ve kemik kırıklarına aşamalı bir yaklaşımın nihai tedavi sonuçlarına etkisini değerlendirmektir.

Gereç ve Yöntem: Bu çalışmada 2015-2020 yılları arasında ateşli silahla ilişkili ekstremite yaralanması olan ve cerrahi tedavi uygulanan 18 yaş üstü hastalar retrospektif olarak değerlendirildi. Hastaların demografik özellikleri, yaralanma bölgeleri, eşlik eden nörovasküler yaralanmalar, ilk müdalede yapılanlar, son tedavi sonuçları, gelişen komplikasyonlar ve komplikasyonların yönetimi değerlendirildi.

Bulgular: Çalışmaya katılan 54 hastanın (52 erkek, 2 kadın) yaş ortalaması 28,3 (yaş aralığı 19-61) idi. Yirmi dokuz (\%53,7)'si alt ekstremite, $20(\% 37,1)$ 'si üst ekstremite ve $5(\% 9,2)$ 'i hem alt hem üst ekstremite yaralanması tespit edildi. Üç $(\% 5,5)$ hastada damar yaralanması, $3(\% 5,5)$ hastada amputasyon ve $6(\% 11,1)$ hastada sinir yaralanması tespit edildi. Altı hastanın beşine $(\% 9,2)$ fasyotomi uygulandı. En sık karşılaşılan komplikasyon olarak 7 (\%12,9) hastada eklem hareket açıklığı kaybıydı.

Sonuç: Ateşli silah yaralanmalarında multidisipliner ve hasar kontrollü bir yaklaşımla erken dönemde antibiyoterapi, kemik tespiti ve seri debridmanlar sonrası nihai tedaviye geçilmesi tedavi başarısını olumlu yönde etkilemektedir.

Anahtar Kelimeler: Ateşli silah yaralanmaları, nörovasküler yaralanma, fasiatomi, komplikasyonlar

Corresponding (Illetişim): Abbas Tokyay, Van YuzuncuYıl University Faculty of Medicine, Department of Orthopedics and Traumatology, Van, Turkey

E-mail (E-posta): dr.abbas_tokyay@hotmail.com

Received (Geliş Tarihi): 25.06.2021 Accepted (Kabul Tarihi): 30.09 .2021 


\section{INTRODUCTION}

Recently, firearm injuries are among the most common causes of admission to emergency departments. ${ }^{[1]}$ The type of firearm, the firing distance, the entry and exit points of the bullet, the characteristics of the injured area and tissues determine the treatment approach. ${ }^{[2,3]}$ Successful results can be obtained with a multidisciplinary approach in the treatment of such complex injuries that affect many systems in the body. In the emergency room, basic life support is provided to the patients with firearm wounds as the first aid and then the intervention by the relevant branch is performed. Extremity wounds are common in firearm injuries. ${ }^{[4]}$ Many complications such as soft tissue injuries, neurovascular injuries and bone fractures are seen in the extremity.Firearm injuries to the extremities more frequently occur in young people and medico-legal problems arise because they are forensic events. ${ }^{[5]}$

Management of the approach to these patients begins with the first medical and/or surgical intervention and continues until the end of the final treatment. With a multidisciplinary and stepwise treatment approach, first of all, control of the bleeding, and infection and then planning bone and soft tissue reconstruction reduce the morbidity rates. ${ }^{[5]}$ Interinstitutional cooperation is needed to minimize complications and to prevent emerging possible medico-legal problems in such injuries.

Our aim in this study is to evaluate the effects of the approach to neurovascular structures, soft tissue debridements, prophylactic antibiotics and temporary and permanent fixation in bone fractures on the final treatment results as a first line treatment in the firearm-related extremity injuries.

\section{MATERIAL AND METHOD}

In this study, patients over the age of 18 who underwent surgical treatment and follow-up due to firearm -related extremity injuries between 2015 and 2020 were evaluated. This study, which was planned as a retrospective cohort study, included patients registered in the archives of our hospital due to a firearm injury, emergency physicians requested a consultation from the Orthopedics and Traumatology department and surgery was planned. Demographic characteristics of the patients, injured extremity, accompanying neurovascular injuries, orthopedic interventions from the first admission to the end of treatment and complications were evaluated.

After the first intervention in extremity injuries, radiographs, computed tomography (CT) and angiography are performed according to the general condition of the patient and the type of trauma (Figure 1,2).

All patients with extremity fractures as a result of gunshot wounds were evaluated according to the Gustilo and Anderson classification and the same protocols were applied. ${ }^{[6]}$ The patients were priorly assessed with damage control approach specific to the type of trauma that occurred. Superficial tissue wounds were cleansed and debrided in the emergency room after bleeding control was achieved with a stepwise treatment approach.

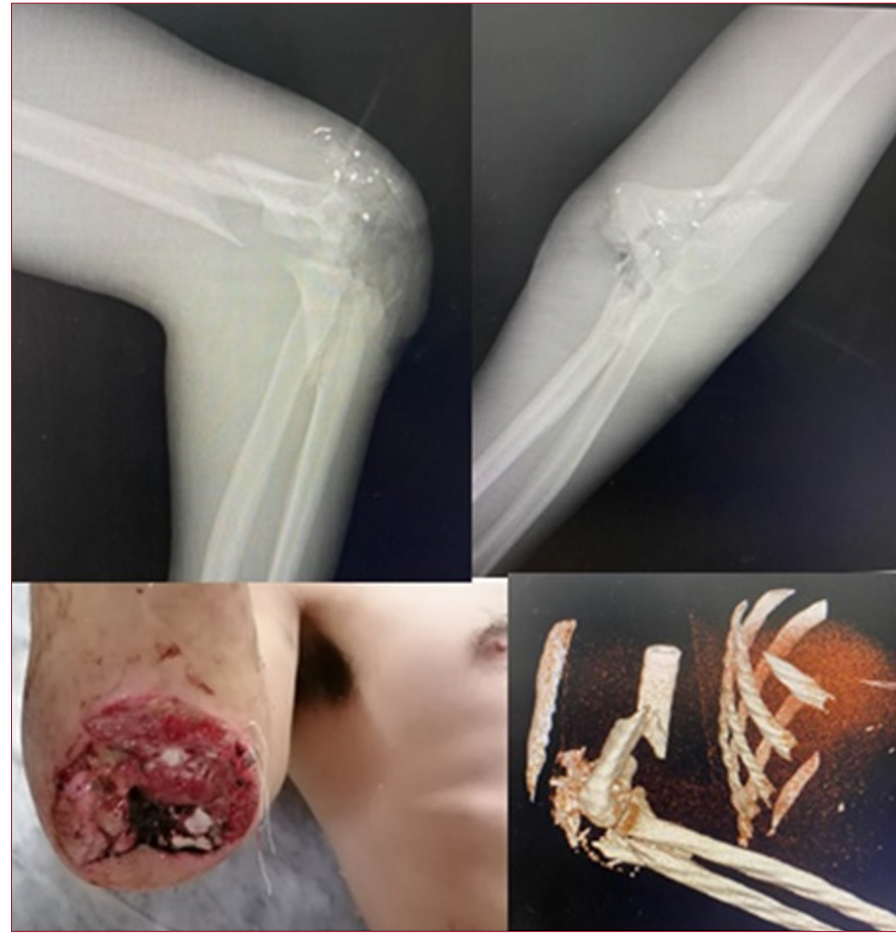

Figure 1. Radiography and CT of a patient with upper extremity injury

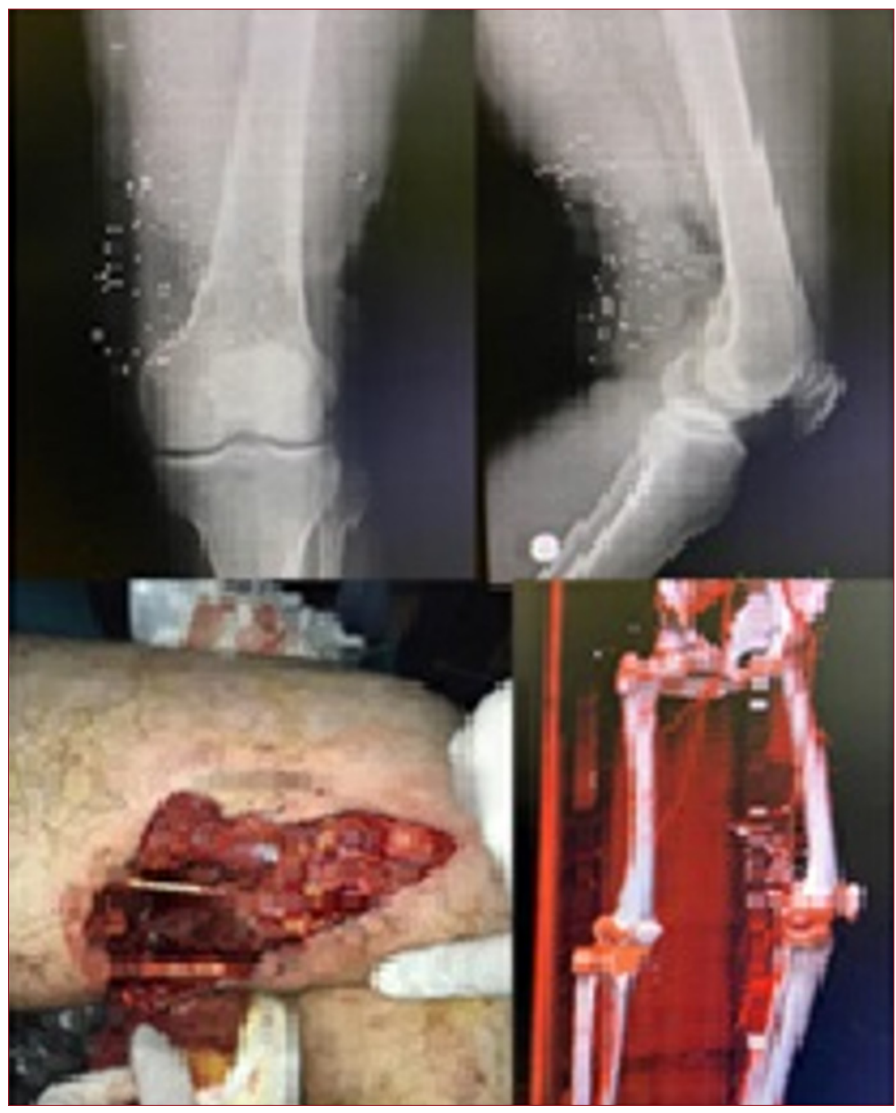

Figure 2. Radiography and Angiography of a patient with lower extremity injury 
The entry and exit points of the bullet were closed with sterile dressing, then antibiotherapy and tetanus prophylaxis were administered. After hemodynamic stabilization was achieved in all patients at the first admission, antibiotics were started and continued for the first 48-72 hours. Depending on the condition of the wound, first-generation cephalosporin and aminoglycoside as a dual antibiotic, or metronidazole as a third antibiotic were added to the antibiotherapy of the patients with contaminated wounds. Patients with deep muscle and bone injuries were operated on and more detailed irrigation and debridement were performed.

Neurovascular and soft tissue injuries requiring reconstruction were evaluated in more detail in the operating room. While vascular injuries and total or near-total nerve cuts were primarily repaired, patients with neurological findings but nerve integrity, and contuinity were not intervened. Before and after all these procedures, the relevant forensic minutes and consent forms were obtained from the patient, if the patient was conscious, if not fromthe patient's relatives.

\section{Statistics}

Descriptive statistics for emphasized continuous variables were expressed as mean, and standard deviation, while for categorical variables it is expressed as numbers and percentages. SPSS (ver: 21 ) statistical package program was used for the calculations.

\section{RESULTS}

The mean age of 54 patients (52 males, 2 females) included in the study was 28.3 (age range 19-61) years. Twenty-nine (53.7\%) lower extremity, 20 (37.1\%) upper extremity, and 5 (9.2\%) both lower and upper extremity injuries were detected. Demographic data of our patients are given in Table $\mathbf{1}$.

\begin{tabular}{lccc} 
Table 1. Demographic data of the patients & & \\
\hline & Male & Female & Total \\
\hline Number of patients & 52 & 2 & 54 \\
Mean age & 28.1 & 33.5 & 28.3 \\
Lower extremity & 29 & 0 & 29 \\
Upper extremity & 18 & 2 & 20 \\
Lower and upper extremities & 5 & 0 & 5
\end{tabular}

Vascular injury was present in $3(5.5 \%)$ patients (Popliteal artery in two, and radial artery in one patient) and vascular reconstruction was performed by a vascular surgeon, and no complications developed. Temporary fixation was performed with external fixator in 11 of 17 patients with bone fractures, while osteosynthesis was performed with intramedullary nailing as definitive treatment in 4 patients and with plate-screw in 2 patients. Three of these patients underwent amputation. Forearm -elbow amputation was performed in one, and below-knee amputation was performed in two patients. MESS (Mangled Extremity Severity Score) criteria were used when making the decision of amputation. ${ }^{[7,8]}$ Neurological findings due to nerve injury were detected in $6(11.1 \%)$ patients.
Primary nerve repair was performed when a total transection of the nerves was detected in two patients (one median and one ulnar nerve) during the operation. Four of our patients had preoperative signs of neurologic injury (wrist drop due to radial nerve damage in three patients and foot dropdue to peroneal nerve damage in one patient) and nerve exploration was not performed for these patients and they were followed up. Nerve regeneration was achieved in two of three patients with radial nerve damage within six months, and tendon transfer was performed in one patient one year later, when symptoms of wrist drop persisted. In the patient with peroneal nerve injury, tendon transfer was carried out for the ankle when there was no recovery within one year.Serial soft tissue debridements were performed three times in three patients with large tissue defects at the injury site and twice in two patients before soft tissue reconstruction. Complications seen in the patients are given in Table 2.

\begin{tabular}{|c|c|c|}
\hline & Lower extremity & Upper extremity \\
\hline Compartment syndrome & 4 & 2 \\
\hline Vascular injury & Popliteal artery (2) & Radial artery \\
\hline Nerve injuries & 1 (Peroneal) & $\begin{array}{c}5 \text { (3 Radial, } 1 \text { Ulnar, } 1 \\
\text { Median) }\end{array}$ \\
\hline Amputation & $\begin{array}{l}2 \text { (Below-knee } \\
\text { amputation) }\end{array}$ & $\begin{array}{c}1 \text { (At the level of } \\
\text { wrist) }\end{array}$ \\
\hline Non-union & 2 & 1 \\
\hline $\begin{array}{l}\text { Loss of range of joint } \\
\text { movement }\end{array}$ & 3 & 4 \\
\hline
\end{tabular}

Since the likelihood of the compartment syndrome was high in five patients, fasciotomy was performed in the early period. In one of our patients, fasciotomy was performed due to the development of compartment syndrome during the follow-up. The surgical wounds of two of the patients who underwent fasciotomy were closed primarily, while the other two required skin grafts. Non-union developed in $3(5.5 \%)$ of the patients. In our patient with non-union humerus fracture, osteosynthesis was performed with iliac wing graft and platescrew, while intramedullary fixation was performed on two tibial non-unions using thicker nails.

One of the complications most frequently encountered by us was loss of range of motion. Limitation of joint movement was detected in $7(12.9 \%)$ patients. Patients showing resistance to manipulations were manipulated under anesthesia and functional range of motion was achieved after physical therapy applications. However, severe limitation of motion at the elbow persisted in one patient.

\section{DISCUSSION}

Incidence rates of firearm injuries are increasing worldwide. ${ }^{[4,9]}$ They occur especially in men under the age of 40 and extremity injuries are common. ${ }^{[4,10,11]}$ Similar to the literature, it was mostly seen in young men in our study. In our center, most of the patients with gunshot wounds were treated with stepwise 
treatment protocols. As a stepwise treatment approach, after damage control, the wound is closed after superficial debridement and washing as the first intervention in the emergency room, and antibiotics and tetanus prophylaxis are given.

More detailed debridement and permanent or temporary bone fixation are performed in the operating room. In patients followed up in the service after the first intervention, treatment is planned depending on the severity of the trauma and the response of the patient. The use and duration of antibiotics in gunshot wounds is widely discussed in the literature. ${ }^{[9,11,12]}$ It is mostly accepted as type 3 according to the Gustilo-Anderson classification and antibiotics are recommended. ${ }^{[6]}$ However, there is no consensus in the literature regarding the duration of antibiotic use, and there are studies recommending it to be used between 48-120 hours. ${ }^{[13]}$ Antibiotics were used in all patients for the first three days. Depending on the condition of the wound, first-generation cephalosporin and aminoglycoside as a dual antibiotic, or metronidazole as a third antibiotic were added to the antibiotherapy of the patients with contaminated wounds.

Debridement and temporary external fixation or permanent internal fixation are recommended for these injuries. $[3,4,8,14,15]$ However, discussions on fixation type continue in the literature. In some studies, external fixation has been recommended in high-energy traumas and internal fixation in low-energy traumas. ${ }^{[9,12]}$ In another study, internal fixation was recommended after stabilization of general condition and hemodynamic parameters of the patients was achieved. ${ }^{[1]}$

In the studies performed, it was determined that the living tissues in the wound area became devitalized in the followups after the first debridements. It was found that removing the dead tissues by performing serial debridements on devitalized tissues significantly reduced the infection. $[11,13,14,19]$ In our patients, both internal and external fixation were applied according to the general condition, hemodynamics, type of injury in the extremity and the general condition of the patient. Permanent fixation was performed after adequate debridement in patients with adequate soft tissue coverage. Temporary external fixation was applied to our patients without adequate coverage of soft tissue or who needed more than one debridement. Plate-screw osteosynthesis was performed as internal fixation in two patients with intra-articular fractures with suitable soft tissue components. In the literature, slow healing of fractures due to firearm injuries is seen at rates between $5 \%$ and $8 \%{ }^{[15]}$ Non-union developed at a similar rate in our cases. Successful results were obtained after the second surgical intervention was performed in our patients who developed non-union.

The most common complication in patients was joint stiffness and related limitation of joint range of motion. In the formation of this situation, the main reason was the injury near the joint or the formation of intra-articular comminuted fractures. In addition, it was observed that the physical therapy and rehabilitation program of the patients was not followed very well in the postoperative follow-ups in our region. All patients with joint stiffness were manipulated under anesthesia, but open surgery was not performed. It is thought that this may play a role in the limitation ofjoint range of movement.

A rate of $3-10 \%$ is given regarding the development of compartment syndrome after a firearm injury. ${ }^{[20]}$ In most of our cases, fasciotomy was performed previously in patients with anticipated compartment syndrome. In this type of injuries, fasciotomy is recommended in patients with suspected compartment syndrome due to impaired circulation in the extremities and late effects of gunshot injury. ${ }^{[20]}$ In our study, no serious complication was encountered after this treatment approach to compartment syndrome.

Since neurovascular and bone structures are close to each other, injury to any component increases the risk of injury to the other component. ${ }^{[12]}$ In order to accelerate the treatment in such critical injuries, when vascular injury is suspected,angiography and/or surgical exploration is recommended in the absence of palpable pulse, but in the presence of signs of ischemia, excessive bleeding or an enlarging hematoma. ${ }^{[1,22]}$ Vascular injuries are repaired in the early period, but surgical approach is not recommended for nerve injuries. Since most of the nerve injuries are detected as neuropraxia and axonotmesis, in the literature their spontaneous recovery is reported to be high within 3-9 months. ${ }^{[22,23]}$

Vascular reconstruction was performed in two popliteal and one radial artery injury in our patients. Spontaneous relapses occurred in most of our cases with neurological injuries. However, in two of our patients, the neurologic injuries did not heal, and the related tendon transfers were performed at the end of the first year. Our most serious complication was amputations in three of our patients. The decision of these amputations was made on the basis of the Mess score scoring criteria. ${ }^{[7,8]}$ The patients were consulted to the psychiatry, physical therapy and rehabilitation and orthotics-prosthesis departments with a multidisciplinary approach for the problems they would experience due to loss of an extremity before amputation.

\section{CONCLUSION}

In summary, although there is no consensus in the literature on debridement in gunshot wounds, bone fixation technique, antibiotic prophylaxis, and approach to neurovascular injuries in firearm injuries, the most common opinion dictates bleeding control with a multidisciplinary approach after damage detection, serial debridements, antibiotherapy, bone stabilization, appropriate approach to neurovascular injury, intensive rehabilitation and appropriate follow-up.

Individualized treatment planning with a multidisciplinary, damage-controlled and stepwise treatment approach will increase success in traumas due to gunshot wounds. In addition, we believe that in this period, the medico-legal problems that may occur will be minimized by informing the patients in detail and taking the records regularly. 


\section{Limitation}

There are several limitations in our study. It is retrospective, the number of patients is small, and the type and distance of the firearm is not known.

\section{ETHICAL DECLARATIONS}

Ethics Committee Approval: The study was approved by the Van Yüzüncü Yıl University Non-interventional Clinical Research Ethics Committee, Decision no:2021/06-05.

Informed Consent: Because the study was designed retrospectively, no written informed consent form was obtained from patients.

Referee Evaluation Process: Externally peer-reviewed.

Conflict of Interest Statement: The authors have no conflicts of interest to declare.

Financial Disclosure: The authors declared that this study has received no financial support.

Author Contributions: All of the authors declare that they have all participated in the design, execution, and analysis of the paper, and that they have approved the final version.

\section{REFERENCES}

1. Burg A, Nachum G, Salai $M$, et al. Treating civilian gunshot wounds to the extremities in a level 1 trauma center:our experience and recommendations. Isr Med Assoc J. 2009;11(9:546-51.

2. Persad IJ, Reddy RS, Saunders MA, Patel J. Gunshot injuries to the extremities:experience of a U.K. trauma centre. Injury. 2005;36(3):407-11.

3. Lerner A, Fodor L, Soudry M. Is staged external fixation a valuable strategy for war injuries to the limbs? Clin Orthop Relat Res. 2006;448:217-24.

4. Kaim Khani GM, Humail SM, Hafeez K, Ahmed N. Pattern of bony injuries among civilian gunshot victims at tertiary care hospital in Karachi, Pakistan. Chin J Traumatol. 2015;18(3):161-3.

5. Penn-Barwell JG, Brown KV, Fries CA. High velocity gunshot injuries to the extremities:management on and off the battlefield. Curr Rev Musculoskelet Med. 2015;8(3):312-7.

6. Tejan J, Lindsey RW. Management of civilian gunshot injuries of the femur. A review of the literature. Injury. 1998;29 Suppl 1:SA18-22.

7. Johansen K, Daines M, Howey T, Helfet D, Hansen ST Jr. Objective criteria accurately predict amputation following lower extremity trauma. J Trauma. 1990;30(5):568-72.

8. Durrant CA, Mackey SP. Orthoplastic classification systems:the good, the bad, and the ungainly. Ann Plast Surg. 2011;66(1):9-12.

9. Graham SM, Wijesekera MP, Laubscher M, et al. Implant-related sepsis in lower limb fractures following gunshot injuries in the civilian population:A systematic review. Injury. 2019;50(2):235-43.

10. Kaçmaz İ, Uzakgider M, Basa C, Zhamilov V, Duman Ö, Karaman G, Ağuş $H$, Ekizoğlu O. Acil tıp kliniğine başvuran ve ortopedi ve travmatoloji konsültasyonu yapılan erişkin adli olguların geriye dönük analizi. Dokuz Eylül Üniversitesi Tıp Fakültesi Dergisi. 2020;34(1):43-52.

11. Dar GN, Tak SR, Kangoo KA, Dar FA, Ahmed ST. External fixation followed by delayed interlocking intramedullary nailing in high velocity gunshot wounds of the femur. Ulus Travma Acil Cerrahi Derg. 2009;15(6):553-8.

12. Abghari M, Monroy A, Schubl S, Davidovitch R, Egol K. Outcomes Following Low-Energy Civilian Gunshot Wound Trauma to the Lower Extremities:Results of a Standard Protocol at an Urban Trauma Center. lowa Orthop J. 2015;35:65-9.

13. Tisnovsky I, Katz SD, Pincay Jl, Garcia Reinoso L, et al. Management of gunshot wound-related hip injuries:A systematic review of the current literature. J Orthop. 2020;23:100-106.
14. Dar GN, Tak SR, Kangoo KA, Dar FA, Ahmed ST. External fixation followed by delayed interlocking intramedullary nailing in high velocity gunshot wounds of the femur. Ulus Travma Acil Cerrahi Derg. 2009;15(6):553-8.

15. Khatri JP, Kumar M, Singh CM. Primary internal fixation in open fractures of tibia following high-velocity gunshot wounds:a single-centre experience. Int Orthop. 2020;44(4):685-91.

16. Seng VS, Masquelet AC. Management of civilian ballistic fractures. Orthop Traumatol Surg Res. 2013;99(8):953-8.

17. Subasi M, Kesemenli C, Kapukaya A, Necmioglu S. Treatment of intertrochanteric fractures by external fixation. Acta Orthop Belg. 2001;67(5):468-74.

18. Woolum JA, Bailey AM, Dugan A, Agrawal R, Baum RA. Evaluation of infection rates with narrow versus broad-spectrum antibiotic regimens in civilian gunshot open-fracture injury. Am J Emerg Med. 2020;38(5):934-9.

19. Nguyen MP, Reich MS, O'Donnell JA, et al. Infection and Complications After Low-velocity Intra-articular Gunshot Injuries. J Orthop Trauma. 2017;31(6):330-3.

20. Burg A, Nachum G, Salai M, et al. Treating civilian gunshot wounds to the extremities in a level 1 trauma center:our experience and recommendations. Isr Med Assoc J. 2009;11(9):546-51.

21. Smith RF, Elliot JP, Hageman JH, Szilagyi DE, Xavier AO. Acute penetrating arterial injuries of the neck and limbs. Arch Surg. 1974;109(2):198-205.

22. Volgas DA, Stannard JP, Alonso JE. Current orthopaedic treatment of ballistic injuries. Injury. 2005;36(3):380-6.

23. Wiss DA, Brien WW, Becker V Jr. Interlocking nailing for the treatment of femoral fractures due to gunshot wounds. J Bone Joint Surg Am. 1991;73(4):598-606. 